\title{
Dengue in the South-eastern region of Brazil: Historical analysis and epidemiology
}

\author{
José Carlos Serufo*, Andréa Marcia Souza*, Valéria Aparecida Tavares*, Marcos Cézar Jammal**, \\ Josimar Gerônimo Silva**
}

\begin{abstract}
SERUFO, J. C. et al. Dengue in the South-eastern region of Brazil: Historical analysis and epidemiology. Rev. Saúde Pública, 27: 157-67, 1993. The aim of the study is an historical analysis of the work undertaken by the Public Health organizations dedicated to the combat of the Aedes aegypti, as well as an epidemiolocal study of persons with unexplained fever, with a view to evaluating the ocurrence of dengue within the population. The Mac-Elisa, Gac-Elisa, hemaglutination inhibition, isolation and typage tests were used. Organophosphate intoxication in agricultural workers was also assessed by measuring concentrations of seric cholinesterase. A sera samples of 2,094 were collected in 23 towns, and the type 1 dengue virus was detected in 17 towns and autochthony was confirmed in 12 of them. The cholinesterase was measured in 2,391 sera samples of which 53 cases had abnormal levels. Poisoning was confirmed in 3 cases. Results reveal an epidemic the gravity of which was not officially know. The relationshipe between levels of IgM and IgG antibodies indicates the outbreak tendency. The widespread distribution of the vector is troubling because of the possibility of the urbanization of wild yellow fever, whereas the absence of $A$. aegypti in 2 towns with autochthony suggests the existence of another vector. Since there is no vaccine against dengue, the combat of the vector is the most efficient measure for preventing outbreaks. The eradication of the vector depends on government decisions which depend, for their execution, on the organization of the Health System and the propagation of information conceming the prevention of the disease using all possible means because short and long term results depend on the education and the active participation of the entire population.
\end{abstract}

Keywords: Aedes. Mosquito control, methods. Dengue, epidemiology. Pesticides, adverses effects.

\section{Introduction}

Dengue is an acute systemic viral infection that varies clinically from a non symptomatic form, and a classical form with fever, myalgia and artralgy to the most severe form, described in 1954 and known as dengue haemorrhagic fever (DHF). The most severely affected patients with DHF present with the dengue shock syndrome (DSS) which may or may not be reversible and the pathogeny of which is not well known (Halstead', 1980; Martinez et al ${ }^{10}, 1987$ ).

The dengue virus is transmited by a cycle that involves human beings and mosquitoes. The Aedes aegypti is the major vector, but other species like the Aedes albopictus (Clarke \& Casals ${ }^{1}$, 1965), Aedes africanus, Aedes leuteocephalus, Aedes opok, Aedes taylori and Aedes furcifer (Glu-

\footnotetext{
* Virology Service. Division of Biological Medicine. Ezequiel Dias Foundation. Belo Horizonte, MG . Brazil

** Reference Laboratory of the Regional Directorate of Health of Uberaba - Uberaba, MG - Brazil
}

Reprints: J. C. Serufo - Rua Conde Pereira Carneiro, 80 Gameleira - 30550-010 - Belo Horizonte, MG . Brazil bler $\left.^{5}, 1987\right)$ are also vectors. Currently, four types of dengue viruses (DEN-1, 2, 3, 4) as well as several subtypes have been described.

The A. aegypti is the only vector in Minas Gerais State, Brazil, that has already been identified although other species have been found in the country. This mosquito is also the vector of urban yellow fever that caused numerous deaths in the early decades of this century. A study performed by the "Serviço Nacional de Febre Amarela", inaugurated in 1940 , revealed that $63 \%$ of Brazilian counties were infected by $A$. aegypti. This institution inspected $4,702,439$ buildings and 268,576 locations in 1,882 towns of the 1,894 counties existing in the entire country at that time (Franco ${ }^{3}, 1969$ ).

The so called "anti-aegypti service" visited $617,021,537$ homes and treated $3,414,210,354$ reservoirs between 1931 and 1958. This great effort permitted the authorities of the XV Panamerican Health Congress to conclude that the $A$. aegypti had been exterminated in Brazil. These sanitary measures were being widely applied when, in 1967, the vector was detected in Belem, the capital of the Pará state (Franco ${ }^{3}, 1969$ ).

The presence of the vector worries authorities because of the possibility of reinfection with urban 
yellow fever, in addition to dengue which is a world wide public health problem. The dengue epidemic affect hundreds of people mainly in tropical areas of Asia, Oceania, Africa, Australia and the Americas. The tropical areas are those most likely to harbor $A$. aegypti. Early in the century, serious epidemics occured in the Southern United States (1922), Australia (1942-1945), Vietnam (1969), Puerto Rico (1963), Venezuela (1964), Columbia (1971-1972), Jamaica (1977) and Cuba (1977-1978 and 1981) (Secretaria de Estado da Saúde, S. Paulo ${ }^{18}$, 1987).

DHF has caused serious epidemics in the cities of Southeastern Asia with more than 1,5 million cases and 3,000 deaths since 1950 (Monath $^{15}, 1991$ ).

The extension of DHF was evaluated in Thailand: 8,288 cases hospitalized with 310 deaths in 1973 and 7,573 cases with 434 deaths in 1975 (Pinheiro \& Travassos da Rosa ${ }^{17}, 1983$ ).

In Cuba, during the 1981 epidemic, 344,203 cases of dengue, with 110,000 cases that evolved into DHF were registered, presenting fever, hemorrhage, hemoconcentration and shock. The organization of the health services of that country held the number of deaths down to only 158 (Kouri et $\mathrm{al}^{7}, 1982$; Martinez et $\mathrm{al}^{10}, 1987$.

With early care the mortality rate due to DHF was $1-3 \%$, while patients not treated or treated incorrectly have death rates of $50 \%$ (World Health Organization 22 , 1980; Monath $^{15}$, 1991).

The frequency of dengue in S. Paulo (1916) and in Niterói (1923), Brazil, is known. In the territory of Roraima, Boa Vista, dengue affected $20 \%$ of the population in 1982 . Rencently, there have been epidemics in the States of Rio de Janeiro, Alagoas, Ceará, Minas Gerais, S. Paulo and Bahia (Secretaria de Estado da Saúde, S. Paulo ${ }^{18}$, Minas Gerais ${ }^{13}$ ). In 1990, dengue affected the northeastern region of $S$. Paulo and Mato Grosso do Sul State for the first time; Rio de Janeiro presented a second epidemic with thousands of cases of classical dengue and hundreds of cases of the hemorragic form of the disease (Marzochi ${ }^{11}, 1987$; Nogueira et al ${ }^{16}, 1988$ ).

The first cases of autochthonous dengue transmission in Minas Gerais were registered in 1987, in the city of Pirapetinga, in the eastern region of the State known as the "Zona da Mata Mineira", near the boundary with Rio de Janeiro State; 535 cases were notified and serious infections due to both $A$. aegypti and $A$. albopictus were observed. Other towns in this region, like Leopoldina and Mar de Espanha, also presented autochthonous dengue in that same period. This outbreak was self eliminating, and there have been no new cases in the last 3 years (Secretaria de Estado da Saúde ${ }^{14}, 1991$ ).
According to the Epidemiological Surveillance of the Health Secretariat of Minas Gerais (VE/SES/MG) and of the Health District of Uberaba of the National Health Foundation of the Minas Gerais (DS/FNS/MG), there are towns infected with the $A$. aegypti in the Triângulo Mineiro region, situated in the western part of Minas Gerais State, $540 \mathrm{~km}$ from the Zona da Mata. Officially these were 267 cases of dengue and 4 counties with autochthonous dengue still existing in 1991.

Since there is no vaccine against this diasease, the eradication of the vector is the only way to prevent the occurrence of outbreaks of dengue. It is possible to eradicate the vector, but to avoid reinfection in Brazil, integrated efforts with neighboring states and countries are essential (Halstead ${ }^{6}$, 1980; Tauil ${ }^{20}, 1986$ ).

In view of the fact that the epidemic that occurred in Rio de Janciro State in 1990 was caused by the type 2 virus and that which occurred in $S$. Paulo State was caused by the type 1 virus, it is almost certain that the dengue outbreak that occurred in the Triângulo Mineiro region was caused by the dengue virus type 1 , due to the proximity, business exchange and transit of persons between the two States. However, the introduction of the type 2 virus in the Triângulo Mineiro region, coming from Rio de Janeiro or from another State, or even the introduction of another virus type cannot be discarded.

The control of A. aegypti in Brazil during recent decades is analysed in this paper, initially because of the existence yellow fever and at present because of dengue. It is also important to evaluate the official bulletins, which give the cases notified by the public health network and diagnosed by the Virology Service of the Ezequiel Dias Foundation (SV/FUNED).

The consequences of the large scale use of pesticides with a view to the control of the vector and their effects on the health of the workers are here discussed. The mapping of dengue in the Triângulo Mineiro region is attempted by means of an epidemiologic study that will help health authorities by complementing official data and in this way provide an important data base for vector control and epidemiologic surveillance.

\section{Material and Method}

\section{Area description}

The Triângulo Mineiro is located in the western part of Minas Gerais State, in Brazil's Central highlands, having a common boundary with S. Paulo 
State to the south. It is a region given over to stock breeding and has a tropical climate and savana type vegetation. It has a total of 49 counties, which are grouped under one regional health office: the Regional Health Directorate (DRS) in Uberaba, Uberlândia, and Ituiutaba, each county having its own health service. The DRS-Uberaba is a reference laboratory in public health.

\section{Methodology}

1 - Inventory of existing data related to vectorial distribution and cases of dengue.

a) Epidemiologic surveillance data from the Health Secretariat of S. Paulo State, the Superintendancy for Endemic Control of S. Paulo State (SUCEN-SP) and the Regional Office of the National Health Foundation of S. Paulo, all in the neighboring State of S. Paulo.

b) Data from the SV/FUNED, the VE/SES/MG and the Regional Office of the National Health Foundation of Minas Gerais (ER/FNS/MG), in the Triângulo Mineiro region.

2 - The accessing of the program for combatting the vector and its influence in the life of workers, using data on county by county vector distribution and the concentration of cholinesterase in blood samples taken from workers in contact with insecticides.

\section{3 - Mapping dengue in the Triângulo Mineiro re-} gion.

a) Identification of suspected outbreaks, using information provided by the DRS responsible for epidemiologic surveillance in the region.

b) Counties by counties collection of blood samples from individuals with acute fever persisting for more than 6 months and survey of clinical and epidemiologic data collected between September, 1991 and March, 1992.

c) Estimation of seric immunity to dengue by the determination of $\operatorname{IgM}$ and $\operatorname{IgG}$ antibodies using $\mathrm{HI}$ and Elisa.

d) Isolation and typage of viruses circulating in the region.

e) A complementary survey of clinical and epidemiologic data and autochthony detection using Mac-Elisa and isolation in cell culture.

\section{4 - Laboratory Techniques}

a) Techniques of hemagglutination inhibition (HI): The antibody hemaglutination inhibition test was performed with the use of the adapted microplate technique described by Clarke and Casals $^{2}$ (1958). The sera were treated with acetone and absorbed with goose red blood cells to remove inhibitory and non specific agultinins. Antigen DEN-1 produced by SV/FUNED (Prototype dengue virus strain Mochizucki) that was provided by the Virological Department of the Oswaldo Cruz Foundation (DV/FIOCRUZ). The antigen was titred with buffer borate $0.4 \%$ albumin, $\mathrm{pH} 9.0$ to obtain $4 \mathrm{UH} / 0.025 \mathrm{ml}$. The goose red blood cells used in this test were prepared by SV/FUNED.

b) Mac-Elisa: The sera were tested by the use of the capture technique of anti-dengue IgM (Mac-Elisa) described by Kuno et $\mathrm{al}^{8}$ (1987) and standardized for use in Brazil.

c) Gac-Elisa: The sera were tested by the use of the capture technique of anti-Dengue IgG (GacElisa), according to the method developed by SV/FUNED. The sensibilization of microplates was undertaken by the use of human anti-IgG antibodies diluted in carbonate buffer. Bovine albumin plasma was used to stop the reaction. The antigen was the same as was used for $\mathrm{HI}$, diluted in order to obtain $16 \mathrm{UH} / 0.025 \mathrm{ml}$. The sera were used at a screening dilution of 1:50. The anti-dengue-peroxidase was used as a conjugate and TMB was used as substrate. The reFition was stopped by chloride acid 2.5 molar. The reading was performed using the Multiskan II, with a 450 filter.

d) Isolation in cell cultures: The isolation was done in cell cultures of Aedes albopictus - C6/ $36\left(\mathrm{Tesh}^{21}\right.$, 1979) using sera taken from the acute phase of persons said to have the disease ( 2 and 5 days after the beginning of symptoms). The cells were cultured on microplate. The sera were inoculated at a screening dilution of 1:10 in cellular confluent monolayer and were grown in leibovitz (L-15) medium supplemented with fetal bovine serum. The adsorption was favored by intermittent agitation, during 60 minutes, at room temperature. The cell culture was observed over ten days. The indicator for positive results was determined by direct immunofluorescence (Gluber et $\mathrm{al}^{4}$, 1979).

e) Typage: This was undertaken by indirect immunofluorescence using monoclonal antibodies against the 4 types of dengue viruses. The monoclonal antibodies were provided by CDC/Atlanta (USA) and the DV/FIOCRUZ for SV/FUNED.

f) Cholinesterase concentration: The qualitative metho: (Tintometric-calorimetric-Lobivond) was used at field level. A $100 \%-75 \%$ value of enzyme activity is considered normal when compared to the blood of a normal person. The 
samples were submitted to a serial test. The workers with activity $\leq 75 \%$ were given leave of absence from work and quantitative dosages tests were performed on them. The Quantitative Method (kinetic-calorimetric) was carried out in the Regional Laboratory of DRSUberaba using an individual dose commercial kit, performed at $25^{\circ} \mathrm{C}$, with a quality control using a standard serum.

g) Control group: The towns of Fronteira with known autochthony and Ituiutaba with autochthony officially proven by the VE/SES/MG during the period in which of this study was undertaken, were used as controls.

\section{Results}

During work sessions with the DRS of the town of Ituiutaba, MG a recent still unidentified viral infection, whose characteristics suggested dengue, that has affected 3 places in Ituiutaba and in 2 other neighbouring cities, was reported.
The sera were correctly identified and were considered adequate for testing, but the epidemiological register of 13 towns was not complete, which meant that there was insufficient data to determine what the most appropriate test for each phase of the disease would be, e.g., antibody capture assay or dengue virus isolation. A new epidemiological survey of positive cases was performed to verify the existence of autochthony.

Table 1. Dengue cases and autochthony in the Triângujo Mineiro nearby S. Paulo regions, Brazil.

\begin{tabular}{|c|c|c|c|c|}
\hline Region & $\begin{array}{l}\text { Number of } \\
\text { counties in } \\
\text { the region }\end{array}$ & $\begin{array}{l}\text { Source } \\
\text { of } \\
\text { data }\end{array}$ & $\begin{array}{l}\text { Number of } \\
\text { counties with } \\
\text { autochthony }\end{array}$ & $\begin{array}{l}\text { Number of } \\
\text { positives } \\
\text { cases }\end{array}$ \\
\hline $\begin{array}{l}\text { S. Paulo } \\
\text { Triângulo } \\
\text { Mineiro }\end{array}$ & $\begin{array}{l}96 \\
49\end{array}$ & $\begin{array}{l}\text { official (1) } \\
\text { official (2) } \\
\text { this study }\end{array}$ & $\begin{array}{r}37 \\
5 \\
12\end{array}$ & $\begin{array}{r}6.402 \\
267 \\
384\end{array}$ \\
\hline
\end{tabular}

Source: (1) - Superintendency of Endemic Control of S. Paulo State, (SUCEN), 1991.

(2) - Epidemiological Surveillance of the Health Secretariat of Minas Gerais, 1992 (VE/SES/MG) Ezequial Dias Foundation, 1992 (SV/FUNED).

Table 2. Seroepidemiologic survey of dengue cases in the Triângulo Mineiro region according to counties information.

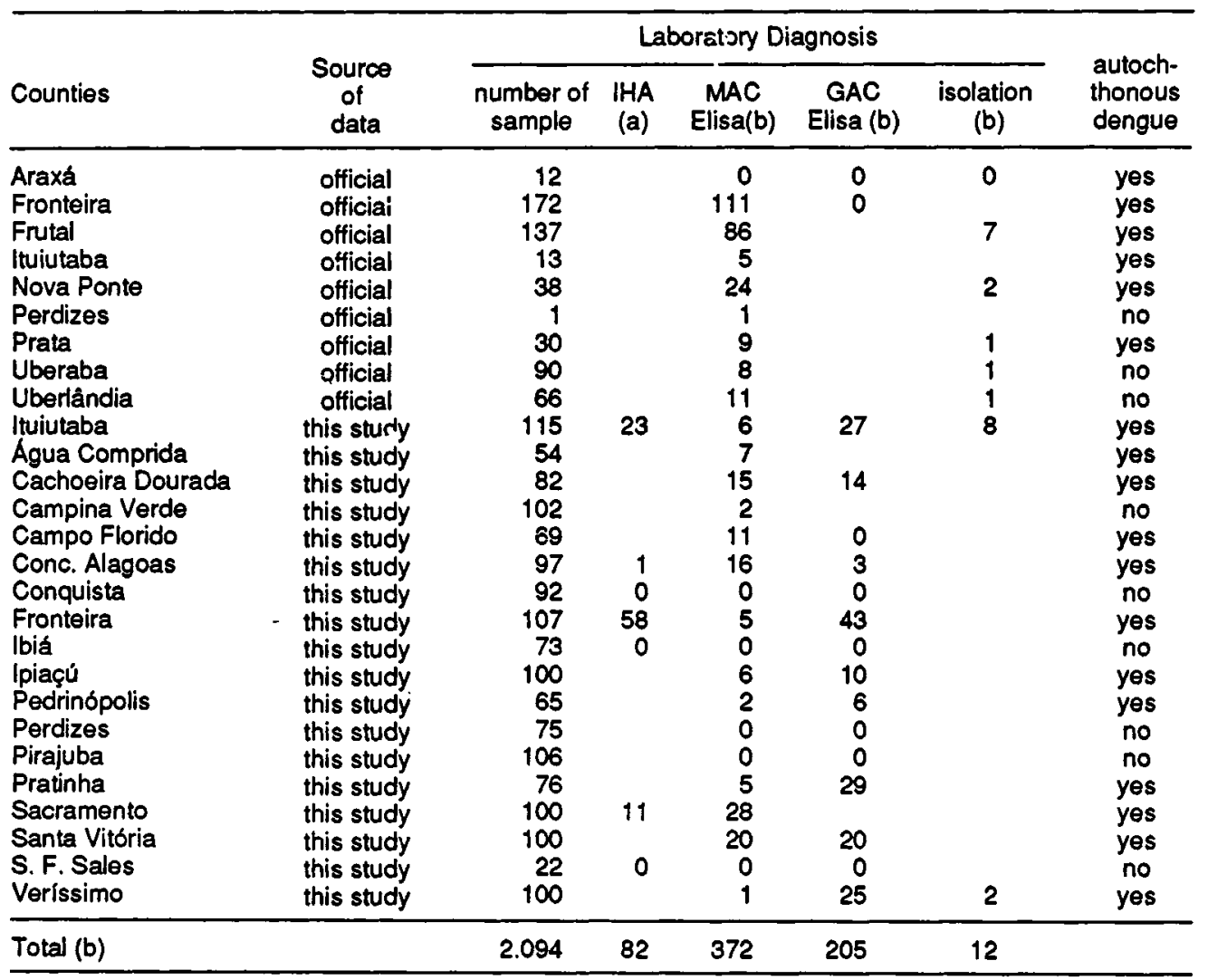

(a) - tites equal or above 1:160.

(b) - positive cases. 
Table 1 shows the occurrence of dengue in the Triângulo Mineiro region and the neighbouring region of the State of S. Paulo. In the Triângulo Mineiro region, the official data showed 5 counties with autochthonous dengue, while in this study was demonstrated authocthony in 12 towns, two of which were known and had already been included in the control group.

Tables 1 and 2 show existing data from the VE/ SES/MG and the SV/FUNED; 559 tests were performed in 9 towns, 267, in 8 towns, being positive, and in 5 towns autochthony was confirmed.

The results of this epidemiological study are shown in tables 2, 3 and 5. Eighteen towns in the Triângulo Mineiro region were surveyed, and 1,535 blood samples were collected from clinical cases with unexplained acute fever. The HI presented titres greater than or equal to 1:160 and correlated with the Gac-Elisa in the 3 towns where both tests were performed. The Mac-Elisa was positive in 13 out of the 18 towns studied and the
Gac-Elisa in 9 out of 18.86 isolation tests were performed with 10 positive results. The typage test using monoclonal antibodies identified the type 1 dengue virus in these 10 sera.

Table 3 presents the levels of seric cholinesterase and shows that 53 persons out of 2,391 on whom the test was performed had an activity of $<75 \%$. Cholinesterase quantitative dosages were

Table 3. Intoxication levels with organophosphate of personel in charge of the insecticides application in the "Triângulo Mineiro" region in the period of November 1991 to April 1992.

\begin{tabular}{lcc}
\hline Method & $\begin{array}{c}\text { Number of } \\
\text { Sample }\end{array}$ & Results \\
\hline Qualitive & 2.391 & 53 with activity under $75 \%$ \\
Quantitative & 53 & 3 with poisoning levels \\
\hline
\end{tabular}

Source: Referencial Laboratory of the Regional Health Directorate of Uberaba (DRS), Health District of Uberaba. National Health Foundation.

Table 4. Organophosphate treatment in counties of the "Triangulo Mineiro" an inventory of index of infection by Aedes aegypti, November 1991 to April 1992.

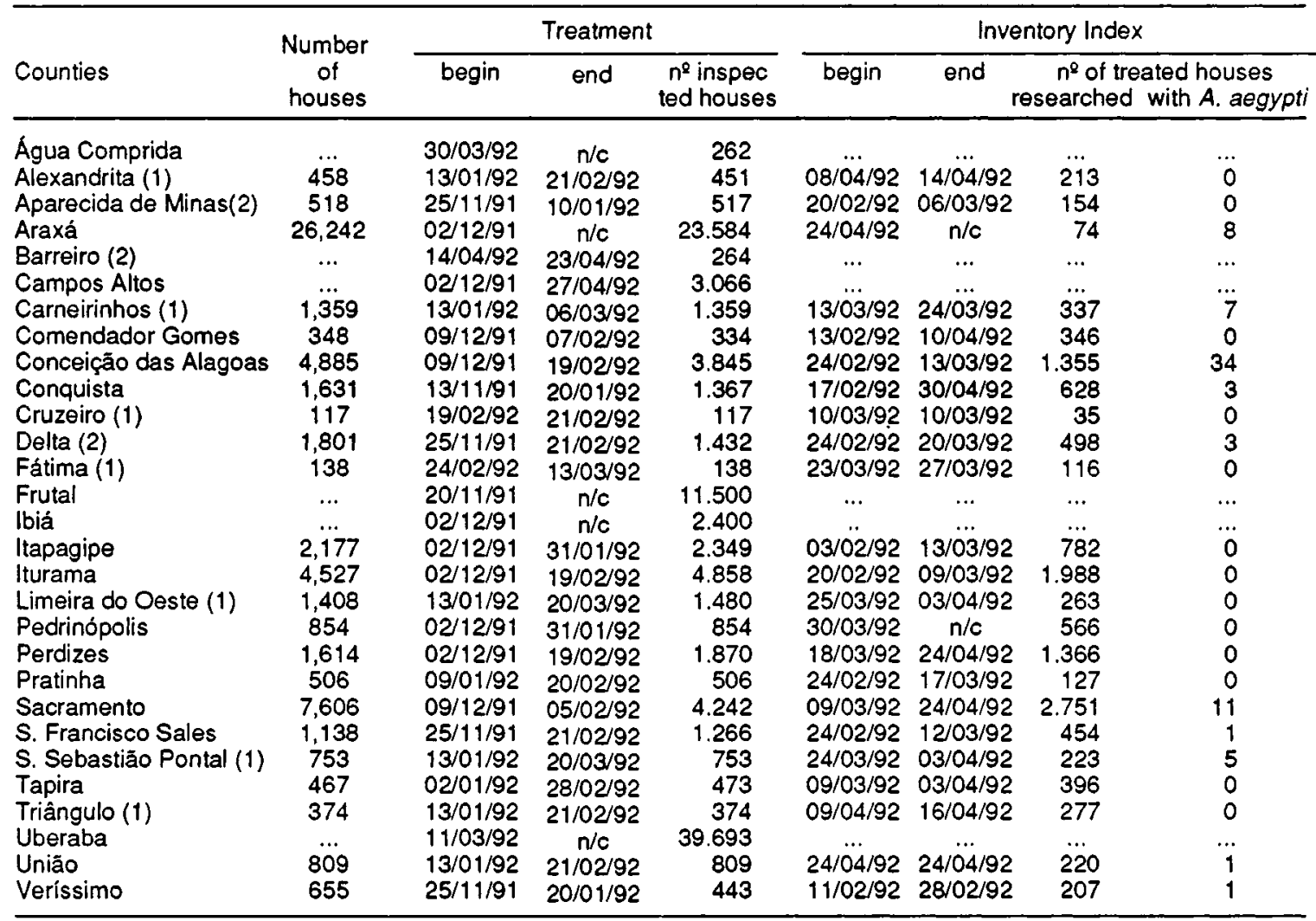

Source: Town hall

Health District of Uberaba National Health Foundation.

Referencial Laboratory of the Regional Health Directorate of Uberaba.

(1) vila (2) distrito $n / c$ not concluded 
Table 5. Laboratory Diagnosis of dengue and certification of autochthony in inhabitants of the "Triângulo Mineiro" region.

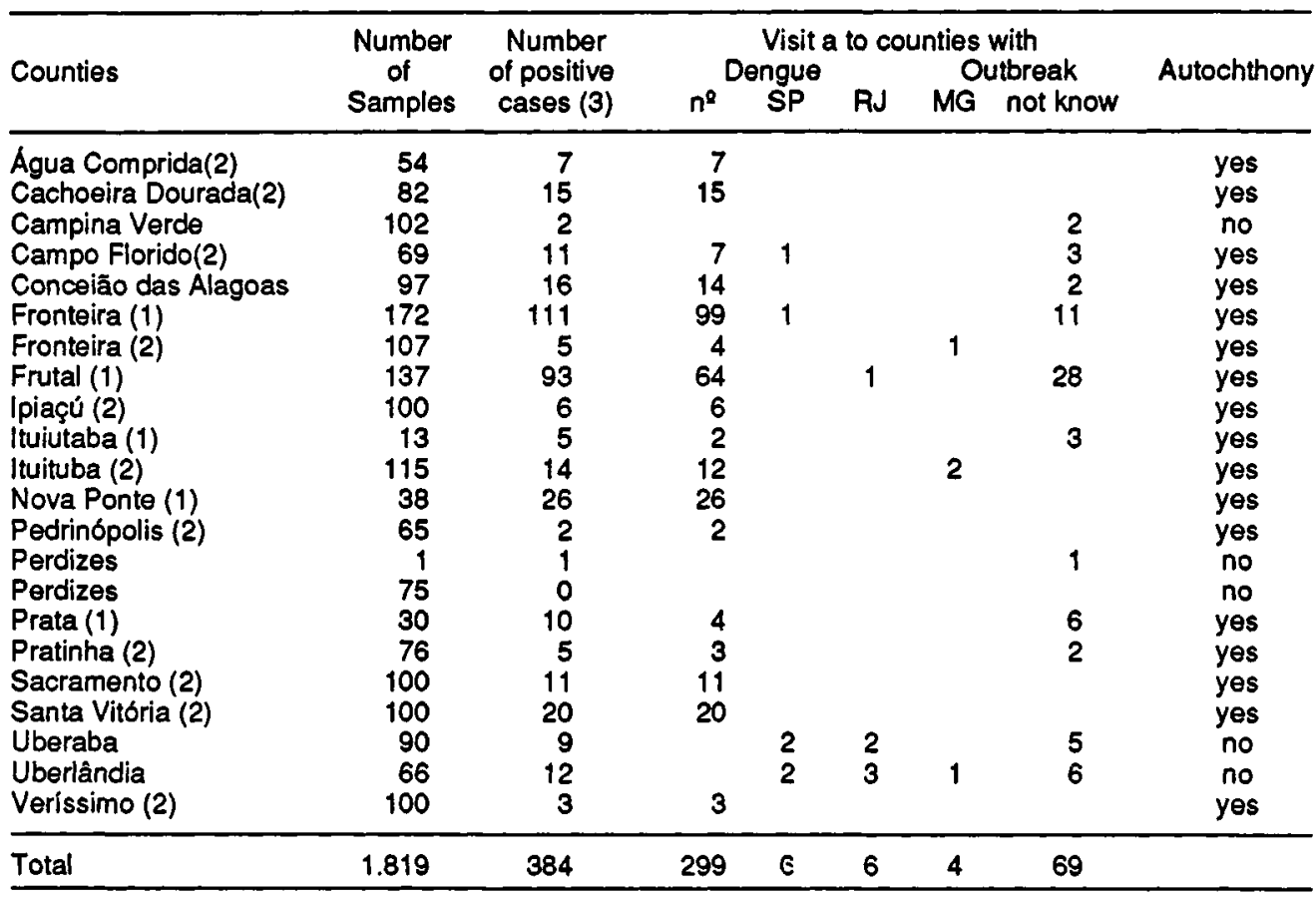

(1) - Counties with officially know autechthony.

(2) - Counties with autochthony detected by this study.

(3) - Positive cases: Laboratory Diagnosis by MAC-ELISA or viral isolation.

performed in these 53 individuals and in 3 cases levels were compatible with poisoning by the insecticides used to combat $A$. aegypti.

Table 4 shows the insecticide treatment of towns in the Triângulo Mineiro and the index of infection by $A$. aegypti. Of the 23 towns studied, this vector was not found in Pedrinópolis and Pratinha.

The occurrence of dengue in the Triângulo Mineiro region and the evidence of autochthony are shown in Table 5 and Figure 1. State Health System Epidemiological Surveillance had detected 5 towns with autochthonous cases. This study revealed 10 other towns, that increasing the number of towns with autochthony to 15 .

\section{Discussion}

The history of yellow fever and the combat against $A$. aegypti in Brazil has revealed errors that should not be repeated, but has also given many examples of efficiency and political and administrative agility that could help determine new, more efficient programs.

In 1943, Soper selected the combat against the $A$. aegypti vector, carried out before his retirement, and that of the Rockefeller Foundation for analysis from among the campaigns undertaken against this vector. According to Soper the period between 1926 and 1940 showed that even if temporary campaigns against the vector in the principal centers had been insufficient to eradicate Brazilian yellow fever, eradication was possible if the techniques developed during this period continued to be applied. If this was followed by continuous vigilance, it would be possible to avoid reinfection by the same species. While in 1926 the measures taken against the $A$. aegypti were both expensive and inefficient in some towns located in the northeastern region of Brazil, according to the International Health Division of the Rockefeller Foundation, in 1940 a well organized national government yellow fever agency was operating throughout the country. Conscious of the direct responsibility of $A$. aegypti for the transmission of yellow fever, the principal aim of this agency was to eradicate the vector from Brazil (Franco ${ }^{3}, 1969$ ).

The results obtained by the National Yellow Fever Service in the eradication of $A$. aegypti were presented during the XI Panamerican Health Conference, held in Rio de Janeiro. That conference, considering the results obtained in Brazil, decided to approve a vote of recognition since 


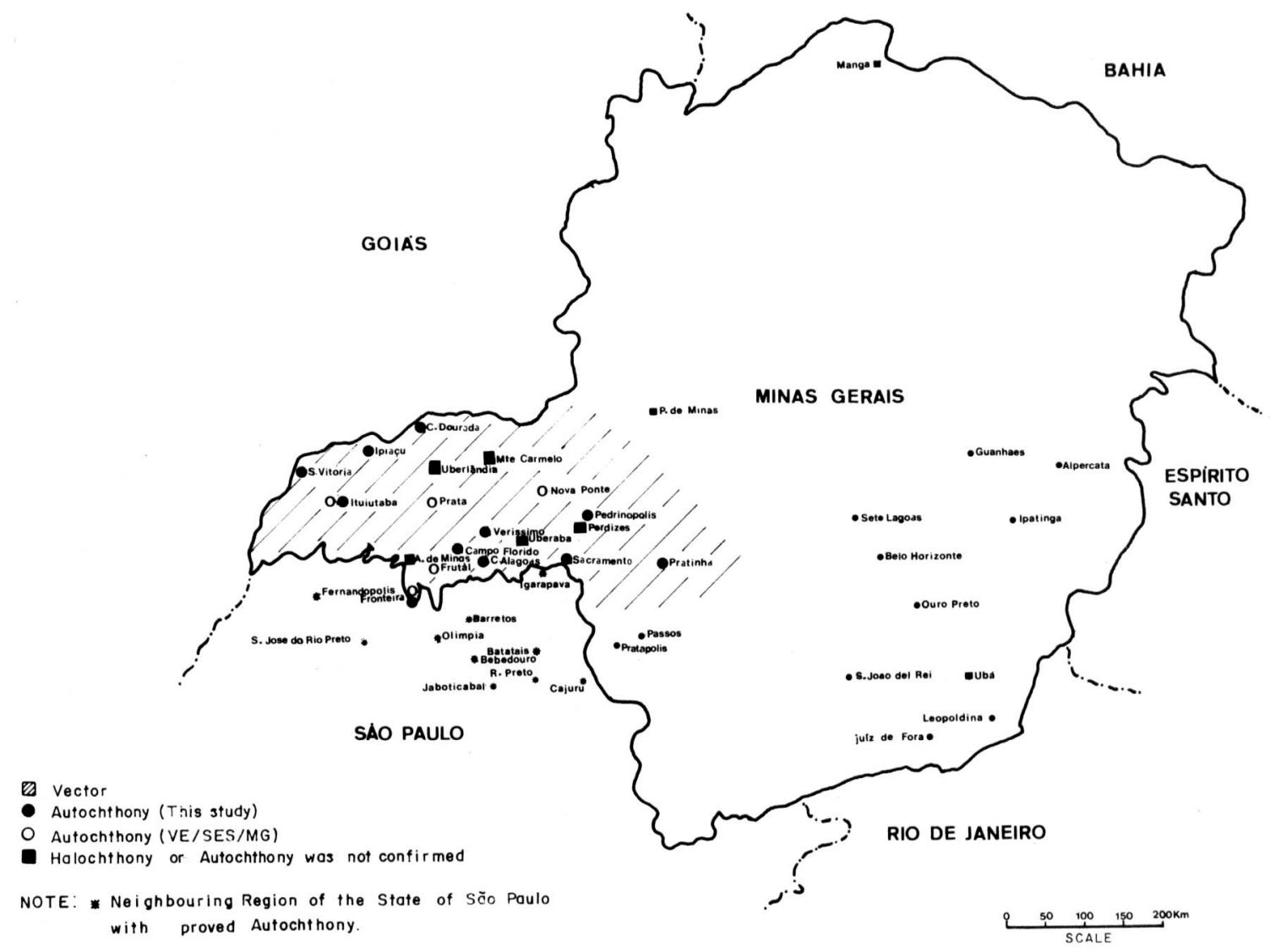

Figure. The occurrence of dengue in the Triângulo Mineiro region Brazil and the evidence of autchthony.

that progress represented a garantee against the spread of yellow fever, and also asked the governments of the countries where the vectors of the disease were located to organize eradication programs based on the methods adopted in Brazil (Franco ${ }^{3}, 1969$ ).

The results obtained both in Brazil, since 1931, and in other South and Central American Countries made it possible, to declare during the XV Panamerican Health Conference, held in Puerto Rico, in 1958, that $A$. aegypti had been eradicated from Belize, Bolivia, Brazil, Equador, French Guyana, Nicaragua, Panama (including the Canal Zone), Paraguay, Peru and Uruguay (Franco ${ }^{3}, 1969$ ).

The disease only reappeared in Brazil on July 26, 1967, when the National Department of Rural Endemic Diseases (DNERu) confirmed a case of reinfection in Belém, Capital of Pará State. It is interesting to note that the case of reinfection in Belém was discovered by accident in March, 1967 , by a doctor who observed a mosquito in his locality that looked like $A$. aegypti, but which he could not identify. On July 20,1967 , he captured another specimen, that was identified as $A$. aegyp- $t i$. With respect to the agility, efficiency and regularity of the measures adopted and their consequences, Franco ${ }^{3}(1969)$ said: "The General Director of DNERu called for the taking of the necessary measures immediately, but in spite of his wishes their implementation was slow." In August, 1967, when the technicians arrived in Belém they found that the infection had already spread all over Belém and in several inland locations, which suggests that the infection had arisen some time before. In August, 1968, they returned to Belem and found that the work had been well organized and that the index of infection for $A$. aegypti had dropped to $0.5 \%$. However, over the following months, in spite of the efforts of the Deputy Director General, certain obstacles slowed the pace of the program: 50 technicians left the agency for administrative reasons, the State suspended 20 men who had been working in the program since the very beginning and soon after hards the supply of the insecticides Abate and Fenthion run out. The Panamerican Health Department had been asked for further supplies of these insecticides early in July, but the DNERu did not receive them until the end of that year. Two tons of gran- 
ulated Abate $1 \%$, purchased on an emergency basis from a company in Rio de Janeiro was not received in time, because the raw material had to be imported from the United States. Because of insufficient manpower and the shortage of appropriate insecticides, the $A$. aegypti index rose to $1.7 \%$ by the end of 1968. Today it is accepted that the eradication of the mosquito is technically possible, but the different institutions involved must join together behind a firm desire to achieve this goal and sufficient financial resources must be made available for the necessary personnel and material for the uninterrupted accomplishement of this task (Franco ${ }^{3}, 1969$ ).

These commentaries, taken from the "History of Yellow Fever in Brazil" (Franco $\left.{ }^{3}, 1969\right)$ show the progress achieved and the setbacks experienced, the burocracy which reflects the fluctuating organizational level of health services in the country, a result of conflicting economic interests, the lack political definition and the lack of constancy in governmental responsibility. Inadequate information of the general population accentuates immobility at all levels.

At the present time, several Brazilian States have foci of infection of $A$. aegypti and register cases of dengue.

Although there is a vaccine against yellow fever, there is none against dengue and vector control is the only way to avoid dengue and its consequences. This also prevents the silver yellow fever, eradicated in 1958, but currently found in urban areas.

The Rio de Janeiro State had an epidemic of dengue in 1986, caused by dengue virus type 1 , which was not efficiently controlled (Marzochi ${ }^{11}$, 1987), and there is now an outbreak of dengue type 2 (Lampe, et $\mathrm{al}^{9}, 1991$ ), associated with DHF. There were 15,084 known cases prior to the last week of 1990, with 106 cases of confirmed DHF and 3 deaths (Secretaria de Estado da Saúde ${ }^{14}, 1991$ ).

In 1986 , according to information given by health area technicians of VE/SES/MG, there was no dengue epidemic in Minas Gerais State. At the beginning of 1991, these health professionals were concerned about the need for an improved and dynamic program of dengue surveillance in Minas Gerais. The dengue outbreak in the Triângulo Mineiro region, in 1991 in the towns of Frutal and Nova Ponte, was confirmed by laboratory tests (Serufo \& Ferreira ${ }^{19}$, 1991).

The results of dengue control depend on a governement decision to combat the vector, to diagnose and treatment the early cases of DHF, as well as on the active cooperation of the population as happened in Cuba in 1981, where the death rate was of only $0.05 \%$ (Kouri, et $\mathrm{al}^{7}, 1982$; Martinez, et al ${ }^{10}, 1987$; Secretaria de Estado da Saúde ${ }^{12}$, 1986). On the other hand, the absence of health service structures and the absence of political definition are associated with an increase in the as was the case in Bangkok, Thailand, where the death rate reached $6.94 \%$ (Pinheiro \& Travassos da Rosa ${ }^{17}, 1983$ ).

Concerning dengue, the goals of Epidemiological Surveillance, must include among others, the knowledge of the distribution of the A. aegypti its density, the presence of other vectors, the establishment of vector control programs, the detection of early signs of outbreaks and appearance of suspected cases, the detection of the virus in mosquito infected areas during interepidemic periods and the evaluation of the susceptibility of the exposed population.

The epidemiological data from the health authorities of the States of S. Paulo and Minas Gerais revealed, on the one hand, 31 towns in S. Paulo State with proved autochthony and, on the other hand, the ubiquity of $A$. aegypti throughout Minas Gerais State despite proved autochthony in only 4 towns. Although the regions are topographically alike, the official epidemiological view of the Triângulo Mineiro region suggests an under registration or the presence of some unknown factor that reduces transmission of the disease.

Both the immobility of the Health Agency and beaurocracy make the articulation of the relevant epidemiological surveillance actions including the vital epidemiologic diagnosis and the choice of priorities difficult. This study was possible because $c i$ the efforts of the authors, and the cooperation of both regional and local technicians, comunity leaders and town comunities as a whole.

The town of Fronteira had already had a dengue outbreak and was included in the control group. The town of Ituiutaba had a dengue outbreak diagnosed by routine SV/FUNED studies and its autochthony was officially confirmed by VE/SES/MG during the realization of this study. Both official data and data obtained in this study for the two towns support the eficiency of the methodology employed.

The antibody hemaglutination inhibition test was generally positive at the end of the first week of the disease and it gives specific reactions in primary infections and intensive cross reactions for flavivirus in patients with secundary infection. However, although it is a rapid, economic and sensitive test, it is not conclusive because of cross reactions with flavivirus when it is performed on a single sample. This technique can be used as an initial test in an epidemiological evaluation, but it must be complemented by the Gac-Elisa to detect IgG associated with past infections. 
The percentage of positive results with GacElisa varied with respect to results obtained by the Mac-Elisa test. Longer persisting IgG antibodies were detected with Gac-Elisa and reflected past infections, while Mac-Elisa detected IgM associated with current infections. Gac-Elisa was used experimentally and its results must be evaluated in future research in order to validate its use in epidemiological evaluations. In this study the results obtained with Gac-Elisa were in agreement with those obtained from autochthony data by $\mathrm{HI}$ and Mac-Elisa.

The Mac-Elisa was used to capture antibodies of class specific IgM for dengue. These antibodies can be detected in 5 days after the first appearance of symptoms, and they remain detectable for 3 months or more. This is a specific test that permits the obtention of quick results using a single blood sample. The detection of IgM antibodies in 12 towns revealed the existence of recent infection in the region, which together with clinical information, confirms autochthony in 10 other towns in addition to the two controls.

The counties of Fronteira, Ituiutaba, Sacramento, Veríssimo and Pratinha show low positive results for IgM with respect to IgG. But the counties Cachoeira Dourada, Campo Florido, Conceição das Alagoas and Santa Vitória have positive results of $50 \%$ or more for IgM. Measurement of both IgM and IgG antibodies in the populations would be useful to indicate the tendency of the epidemic curve.

The isolation of type 1 dengue virus shows that the Triângulo Mineiro region is epidemiologically related with the state of S. Paulo, to is now having an outbreak of type 1 dengue virus.

Recently, the VE/SES/MG and the ER/FNS/ MG have been implementing $A$. aegypti control measures in several towns employing the focus and the perifocus combat in a dengue control project in the State of Minas Gerais. The counties of the Triângulo Mineiro were being treated with insecticides while the samples were being collected. The vector control was being carried out in collaboration with the municipal authorities. But the combat against $A$. aegypti can not be limited to periodic spraying of the urban biosystem as long as the conditions which favor the maintenance of the species continue unmodified.

Intoxication by organophosphates can be easily detected but this is not the case with chronic poisoning. The massive use of these products leads to varying degrees of danger both to the environment and to public health, ranging from mild headaches and nausea to severe neuro-respiratory reactions. The workers handling these products are the most exposed. The dosages of cholinesterase show that the danger is not theoretical: there were 3 cases of intoxication.

The data on A. aegypti infection show that the Aedes aegypti was not detected in two towns with confirmed autochthony, Pedrinópolis and Pratinha. This may be due either to the efficiency of focal and perifocal combat or to the small size of the samples or even to the presence of some other vector.

It is known that $A$. aegypti has a lower susceptibility to infection with dengue viruses than other species such as the $A$. albopictus (Gluber ${ }^{5}, 1987$ ). However, the A. aegypti is a vector that lives in closer relationship with people thus facilitating infection. There are no studies underway concerning other potential vectors or laboratory tests to confirm vectorial infection in state on Minas Gerais.

\section{Conclusion}

The history of the control of A. aegypti in Brazil shows that it is possible to eradicate the mosquito over large areas. The use of insecticides to combat the vector constitutes an efficient method and producer rapid and satisfactory results, but it represents high cost and great danger to environment and workers, as well as possible intoxication of susceptible members of the general population. In addition, the maintenance of these results depend on the constancy of government measures.

The eradication of dengue and continuous vectorial control are possible if health authorities support measures to eliminate vector breeding grounds systematically in close collaboration with the general population. In addition to focal and perifocal combat, it is necessary to invest an equal amount to resources in educational programs and in the diffusion of information adapted to each social class with a view to estimulating an active participation on the part of the population in the establishment and application of dengue eradication programs, in such a way as to avoid inefficient passive, conditioned responses to simplified slogans transmitted by the means of mass communication.

The fight against $A$. aegypti must be begin with a large discussion of the subject within the community as a whole, through the schools by the appropriate training of teachers; through the churches, by the training of priests and pastors; through private organizations, private and public enterprises, trades unions, professional organizations and neighborhood associations by the education of the leaders of these associations.

The region of the Triângulo Mineiro is epidemiologically related to the neighboring region of $S$. Paulo State. One must not lose sight of the possi- 
bility, however, of the possible introduction of the type 2 dengue virus through the transportation networks and the movement of people. The type 2 dengue virus is responsible for the current dengue outbreak in Rio de Janeiro, or for the introduction of another virus type. A second epidemic would involve the additional danger of DHF, that can develop to produce shock and result in death. Besides the human factor, one has to consider the economic and social costs of absence from work or school, the costs of out or in-patient treatment and of laboratory tests. One must also consider the danger that the population, lacking adequate information, may come to accept the disease and see the affliction as part of their destiny.

The presence of the vector in most of the towns of the Triângulo Mineiro region creates the conditions favorable to epidemics of unpredictable proportions. In addition, it increases the possibility of the urbanization of the wild yellow fever which is transmitted by the same vector. The absence of $A$. aegypti in the two towns with autochthony, suggests the existence of another vector in the region. It is therefore imperative to study other vectors and to perform tests to isolate the viruses from these vectors.

Our results reveal a dengue epidemic of hitherts unknown proportions, i.e., official data collected by the health system under-evaluate the epidemiological reality of the region, and very likely of the situation in the State as a whole.

Dengue mapping must be further developed in order to establish the true epidemiological situation of the disease in the State of Minas Gerais and other vectors must be studied with a view to adapting control programs to the presence situation regarding the disease.

Due to the fact that there are 1,435 fever cases negative for dengue it is advisable that the possibility that other virus are the causative agents be investigated.

The aim of this paper is not to propose the realization of continuous epidemiological surveys, but rather to show the urgent need for a unified health system capable of generating essential Epidemiological surveillance information so that epidemiological studies such as this one may become unnecessary.

\section{Acknowledgements}

To the Epidemiological Surveillance Service of the Health Secretariat of the State of Minas Gerais and the technicians of the Uberaba Health District of the National Health Foundation, who kindly gave us epidemiological data related to vector con- trol, to the of the Regional Directorates of Uberaba and Ituiutaba, and the technicians of the Regional Laboratory of Uberaba, for the participation in blood sample collection; to Dr. Geraldo Gerola Júnior, of the Superintendency for the Control of Endemic Diseases of S. Paulo State (SUCEN-SP), who responded to our request for information and trusted then unpublished to us; to Drs. Hermann Schatzmayr and Rita Nogueira of the Virology Departament of the Oswaldo Cruz Foundation; Maria Luiza Barbosa and Iraí Rocco of the Adolfo Lutz Institute, and Amélia Travassos da Rosa and the staff of the Evandro Chagas Institute, who contributed to our professional preparation by giving us technical information and discussing it with us to Benedita Bráz Siqueira, for her essential cooperation in the important technical aspects of this study; to Marcela Montes de Oca and Augusto César Soares dos Santos, for their cooperation; to Dr. Héctor Montes de Oca, whose criticisms of this paper made possible improvements that have helped us achieve greater experience and maturity; and to the blood donators, for the material that permitted the realization of this work.

SERUFO, J. C. et al. [Dengue na região sudeste do Brasil: Análise histórica e soroepidemiologica]. Rev. Saúde Pública, 27: 157-67, 1993. Objetivou-se fazer análise histórica da atuação dos órgãos de saúde no combate ao Aedes aegypti e realizar estudo soroepidemiológico de pessoas com quadro febril não identificado para avaliar a ocorrência de dengue na população do Estado de Minas Gerais, Brasil. Foram utilizados os testes de Mac-Elisa, Gac-Elisa, inibição da hemaglutinação, isolamento e tipagem. Foram avaliados os níveis de intoxicação de trabalhadores por inseticidas organofosforado, através de dosagem da colinesterase. Foram coletados 1.989 soros de pessoas com quadro febril não identificado em $28 \mathrm{mu}$ nicípios, sendo constatada a ocorrência de dengue em 17 e comprovada autoctonia em 14 municípios. Foi isolado sorotipo 1. A dosagem de colinesterase de 2.391 soros mostrou 53 casos com alteraçães, sendo comprovados 3 casos de intoxicação. Os resultados mostraram uma epidemia de proporções maiores do que a oficialmente conhecida. A distribuição ampla do vetor traz inquietação quanto à possibilidade de reurbanização da febre amarela silvestre, enquanto a não deteç̧ão do $A$. aegypti em 2 municípios com autoctonia levanta a possibilidade do envolvimento de outros vetores. Como não existe ainda va: cina contra o dengue, o combate ao vetor é a medida eficaz na prevenção de surtos. A erradicação do vetor depende de decisão govemamental que envolva a organização do sistema de saúde e a participação de todos os meios e formas de repasse de informação, uma vez que o resultado a médio e longo prazo depende especialmente da capacitação popular e sua participação ostensiva.

Descritores: Aedes. Controle de mosquitos, métodos. Dengue, epidemiologia. Praguicidas, efeitos adversos. 


\section{Referências Bibllográflcas}

1. CLARKE, D. H. \& CASALS, J. Arboviruses group B. Horsfall, F. L. \& Tamm, J. L., ed. In: Viral and rickettsial infections of man Philadelphia, 1965. p. 606-58.

2. CLARKE, D. H. \& CASALS, J. Techiniques for haemagglutination and haemagglutination inhibition with arthropod bome viruses. Am. J. Trop. Med. Hyg., v. 7: 56173, 1958.

3. FRANCO, O. A erradicação do "Aedes aegypti". In: Franco, O. Historia da febre amarela no Brasil. Rio de Janeiro, Ministério da Saúde Departamento Nacional de Endemias Rurais, 1969. p. 135-56.

4. GLUBLER, D. J.; SUHRYONO, W.; LUBIS, I; ERAM, S.; SAROSO, J. S. Epidemic dengue hemorhagic fever in nural Indonésia. I. Virological and epidemiological studies. Am. J.. Trop. Med. Hyg, 28: 701-10, 1979.

5. GLUBLER, D. J. Current research on dengue. In: $O^{\prime}$ HARRIS, K. F. ed. Current topics in vector research New York: Spring-Verlag, 1987, 37-56.

6. HALSTEAD, S. B. Dengue haemoarthagic fever: a public health problem and a field for research. Bull. World Health Organ, 58: 1-21, 1980.

7. KOURI, G.; MAS, P.; GUZMAN, M. G.; SOLER, M.; GOYENECHEA, A.; MORIER, L. Dengue hemorrágico en Cuba, 1981: Diagnóstico rápido del agente etiológico. Bol. Of. Sanit. Panam, 93: 1982.

8. KUNO, G.; GOMEZ, I.; GLUBLER, D. J. Detecting artificial antidengue IgM immune complexes using an enzymelinked immunosorbent assay. Am. J. Trop. Med. Hyg., 36: 153-9, 1987.

9. LAMPE, E.; NOGUEIRA, R. M. R.; ARAUJO, E. S. M.; MIAGOSTOVICH, M. P.; SCHATZMAYR, H. G. Dengue infection in Rio de Janeiro, 1990-1991. In: Simpósio Intemacional Sobre Arbovirus dos Trópicos e Febres Hemorrágicas, $2^{2}$ 1991. Belém, Resumos Belém, Instituto Evandro Chagas/Universidade Federal do Para/Sociedade Brasileira de Virologia, 1991.p. 2.

10. MARTINEZ, C. D.; MACHADO, G. F.; TORRES, E. M.; SABATELA, R. C.; HERNANDEZ, E.; CONCEPCION, M. R. Algunos aspectos clínicos durante la epidemia de dengue hemorragico en Cuba. Cad. Saúde Pública, 2: 148-57, 1987.
11. MARZOCHI, K. B. F. Dengue: a mais nova endemia "de estimação"? Cad. Saúde Pública, 2: 137-41, 1987.

12. MINAS GERAIS. Secretaria de Estado da Saúde. Algumas consideraçóes sobre o dengue e plano de açäo para seu controle no Estado de Minas Gerais. Belo Horizonte, 1986.

13. MINAS GERAIS. Secretaria de Estado da Saúde. Informe. Belo Horizonte. 1991. [mimeografado].

14. MINAS GERAIS. Secretaria de Estado da Saúde. Sistema Único de Saúde-SUS. Subprojeto 17: Açöes emergen. ciais para o controle vetorial do dengue em Minas Ge. rais. Belo Horizonte, 1991.

15. MONATH, T. P. Flavivirus: fiebre amarilla. Dengue y encefalitis de St. Louis. In: Manoel, G. L.; Douglas, R. G.; Beneth, J. E. Enfermedades infecciosas: principios e practica. $3^{2}$ ed. Buenos Aires, Editorial Médica Panamericana S. A., 1991. p. 1.315-9.

16. NOGUEIRA, R. M. R.; SHATZMAYR, H. G.; MIAGOSTOVICH, M. P.; FARIAS, M. F. D. B.; FARIAS FILHO, J. C. Virological study of a dengue type 1 epidemic at Rio de Janeiro. Mem. Inst. Oswaldo Cruz, 83: 219-25, 1988.

17. PINHEIRO, F. P. \& TRAVASSOS DA ROSA, J. F. S. Febres hemorrágicas. In: Veronesi R. Doenças infecciosas e parasitárias. 7^ ed. Rio de Janeiro, Editora Guanabara-Koogan, 1983. p. 172-83.

18. SÃO PAULO. Secretaria de Estado da Saúde. Manual de vigiláncia epidemiológica: dengue. São Paulo, 1987.

19. SERUFO, J. C. \& FERREIRA, E. C. Dengue. Belo Horizonte: 1991. [mimeografado].

20. TAUIL, P. L. O problema do Aedes aegypti no Brasil. Rev. Soc. Bras. Med. Trop., 19: 1-3, 1986.

21. TESH, R. B. A method for the isolation and identification of dengue viruses using mosquito cell culture. Am. J. Trop. Med. Hyg., 28: 1.053-9, 1979.

22. WORLD HEALTH ORGANIZATION. Technical Advisory comittee on Dengue Haemorthagic Fever for the South Fast Asian and Westem Pacific Regions. Guide for diagnosis, treatment and control of dengue haemorrhagic fever. Genova, 1980.

Recebido para publicaçäo em 8.10.1992 Reapresentado em 16.3.1993 Aprovado para publicação em 31.3.1993 